\title{
FINANCING HEIS THROUGH WAQF FUND IN BANGLADESH: ISSUES AND POSSIBILITIES
}

\author{
Dr. Muhammad Nazmul Hoque \\ $\mathrm{PhD}$ in Sharih and Economics \\ Academy of Islamic Studies \\ University of Malaya, Malaysia \\ E-mail: mdnazmulum@gmail.com
}

\begin{abstract}
The aim of the paper is to explicate the narrative of waqf fund for funding higher educational institutions (HEIs) in Bangladesh. nowadays, there is the reason for preventing students to pursue their higher education which is costly matters. This paper highlights some problems in implementing waqf fund for financing HEIs in Bangladesh and offer some Easier way to overcome this condition through the implementation of a waqf fund based HEIs. As a qualitative approach, data were gathered by conducting the interview from directors, academician and scholar those who have expertise on the waqf fund-based financing HEIs in Bangladesh. In addition, a review of Waqf literature is placed to examine the present status of Waqf in Bangladesh. The results show that the position of the waqf fund is essential for contributing to the society of Bangladesh and strengthening its financial stability. Taking into consideration that needs and suitable for the higher educational institutions, some problems, and possible solutions have been discussed for the country in order for a transformation in higher education facilities. At the same time, some prospects have been proposed for the country. Raising funds by collecting Hibah /donation, raising funds by different activities and promoting funds from alumni have been proposed for higher education in Bangladesh. This paper discusses the experience of waqf fund implementation in some Malaysian higher educational institutions. It also contains observations from the experience of several past universities.
\end{abstract}

Keywords: Financing HEIs, Waqf, Issues, Possible Solutions.

\section{INTRODUCTION}

The waqf fund includes any establishment that benefits the community especially by educating higher education. As for Shari'ah understanding, it implies holding the property of a person to benefit others. In addition, Mahmood (2006) summarizes and defines the significance of the waqf based on referring to Muslim lawyers from Malaysia "a dedication of property either in expressed terms by implication for any charitable or religious object to secure any benefit for human beings" Therefore, in order to meet the real significance of waqf in Islam, waqf property shall be in good condition, continuous and it is the way of immediate intimacy with Allah for offering others with social protection, welfare, and justice. Thus, the Waqf fund includes any establishment that benefits the community especially by educating higher education. 
Meanwhile, higher educational institutions (HEI) require large amounts of financial aid in order to be developed, functional and operational in full swing. However, many HEI has experienced funding shortages including the most renowned, such as Yale Medical School (Burrow, 2008). Studies show that, in spite of the long tradition of donation in education, Waqf's engagement in financing the education system appeared in Muslim and non-Muslim nations several decades ago, despite having some instances in Ancient times like Al Azhar. Although these nations have used distinct terms, their aim was comparable to waqf, which contributes and collects funds to assist people in need and increase society's quality of life (Mujani, Taib, \& Yaakub, 2016; Argun, 2013). For example, in Turkey, there are various sources of revenue including educational cost charges, installments from government sources, private gifts, stipends, enrichment salary, deals and administrations of educational exercises, assistant endeavors, and independent activities (Argun, 2013; Toutkoushian, 2001).

Amongst the various benefits of waqf, a particularly valuable factor is that it attracts funds from potential donors, such as the public community, corporate institutions, and wealthy individuals. This can help to alleviate financial problems experienced by higher educational institutions who are struggling to develop such institutions and it may contribute further towards the prosperity of the Muslim community. Therefore, it is important to establish and reduce the gap between social-economic factors by providing value-based educational services as an alternative to economic stability. As a result of bridging the attainment gap, the poorer communities will have equal educational opportunities (Duruigbo, 2004). This article starts with the parliamentary provision of Waqf, based on historical insights in Bangladesh from the British period (for example, before 1947). The contention will then show the current statistics and research. This is followed by our information and analysis collected during study interviews. In the succession, few observations are mixed as a means of accessing a Waqf system conversion. The interview has also examined practices and challenges in the field of waqf financing higher education.

\section{LITERATURE REVIEW: AN OVERVIEW OF FINANCING HEIS IN BANGLADESH}

Based on the review, the study, in the beginning, had a look at the legislative ground of Waqf in Bangladesh. As an ex-colony of British, till 1947, Waqf's first legislation was implemented by the colonial administrator in 1894 with the Privy Council statement invalidating the Waqf in the family domain and then abolished and substituted by the "Mussalman Waqf Validating Act" in 1913 (Hasan \& Siraj, 2016). As seen, "the Bengal Waqf Act of 1934" introduced and implemented by the British which was adopted in East Pakistan under an ordinance of 1962 (the name of Bangladesh, 1947-1971) with minor amendments (Azhari, A. S. (2016)). After independence, according to Article 5 of the National Constitution of the "Adaptation of existing Bangladesh Laws" of 1972, the 1962 Waqf Legislation of Pakistan, which was originally taken in 1934, has taken for granted. Surprisingly, the whole Law still applies to the Waqf Administration of Bangladesh with certain adjustments made in it by the "Waqf Ordinance 1988," the "Waqf Ordinance 1998," the "Waqf Act 2013" and the "Waqf (Amendment) Act-2013" . The 1988 Waqf related acts are dealing with Waqf maintenance in Bangladesh, and the 2013 Waqf Special Act establishes a framework for the transfer and growth of Waqf assets in the nation. Understandably, it is a clear legislative lacking to operate and maintenance the waqf sector. In terms of Waqf administration, the information reveals that there are 111 officials are maintaining the whole country of 170 million people (Karim, 2010). In searching the literature on Higher education that is financed by Waqf funding, we saw that this issue is sidelined for some reason. 
However, higher educational institutions in Bangladesh are mainly divided into three types: public, non-government, and fully private under the Ministry of Education. The allocation of the budget also differs. For example, a maximum of $90 \%$ of the budget is allocated for public HEIs, and the other $10 \%$ is generated from other sources. Further, fully private HEI have their own revenue which comes from tuition fees and other income sources. Additionally, the fund allocated for nongovernment (affiliated) HEIs are partly supported, totaling $60 \%$ from the government, and 40\% from own revenue (Rahman, Khan, \& Sabbih, 2016).

Moreover, the fund for public HEIs is allocated a meager $11.5 \%$ from the total national budget. This declined in 2016 from the fiscal year 2007 allocation of $15.9 \%$. This budget is insufficient to meet the demands and needs of public universities. As stated above the cost of higher education in Bangladesh is mostly financed by the government, and the set budget is amongst the lowest in the world. All the public universities in Bangladesh operate with a budget deficit and are often forced to reduce essential expenditures such as equipment, research, and maintenance (Ashraf, Osman, \& Ratan, 2016). It is thus an important issue that the Government of Bangladesh (GoB) needs some sources for generating income from other sources in order to finance HEIs.

In addition to above, GoB, in the official information says that Bangladesh develops religious-based higher educational institutions using waqf fund, where about 8,000 of its learning establishment are funded by waqf fund. Besides this, more than 123,000 mosques are based on waqf, which provides educational and social facilities, especially in imparting religious education. The Bangladesh Statistical Office's conducted official survey of waqf assets in 2016, the below table is provided the number of waqf fund in Bangladesh:

Table1. Number of Waqf Estates Education

\begin{tabular}{|l|l|c|}
\hline No. & Waqf Estates Education & Number of Waqf Estates Education \\
\hline 1 & $\begin{array}{l}\text { Madrasahs (Islamic higher educational } \\
\text { institutions) }\end{array}$ & 9314 \\
\hline 2 & Female (Madrasah) Islamic institutions & 1136 \\
\hline 4 & $\begin{array}{l}\text { The waqf estates house (Educational } \\
\text { purposes) }\end{array}$ & 123,006 \\
\hline
\end{tabular}

Source: Bangladesh Education Statistics, 2016

In above table reveals the list of waqf estates existing till in 2016, which is in the form of real estate properties. Some examples of higher education institutes exist that developed waqf fund for financing their higher learning institutions and many activities such as academic activities, welfare services, and professional programs was developed for fundraising purpose. For example, Hamdard University Bangladesh (HUB), International Islamic University Chittagong (IIUC), and many Islamic higher educational institutions like madrasah aliah and madrasah qawmiyyah are the vanguard in that scheme. In Bangladesh, Studies indicate that the waqf institution has been resurrected with the implementation in new domains of cash waqf which has provided some resources, has helped to set up some greater education organizations, particularly in private universities. The Waqf in intellectual property, as a new addition in waqf, where the copyrights of books are endowed. In Bangladesh, two kinds of waqf fund have been 
identified, one of these having a unique feature that $10 \%$ of the income is spent on education for the needy and ideological reason (Sadeq, 2002).

This brief illustration of waqf fund particularly in Bangladesh provides some indications on the potentials of waqf funds in making contributions to develop the higher educational institution of a country.

Despite this, although Bangladesh has a huge wealth of waqf fund, waqf based fundraising and the development of waqf based projects are yet to develop enough to meet the needs of HEIs (Haron, 1998) and enhance the quality of life (Ashraf, Hassan, \& Hunt-Ahmed, 2013). Meanwhile, similar to Malaysia, the expenditure on education is resultant of a combination of current and capital public spending. The Malaysian government accounts for the expenditure of public and private educational institutes, administration costs, and fund private entities and it has maintained its large investment in the education sector over the 55 years since Malaysia gained independence (Malaysia, 2012). Therefore, several studies have also recommended that the role of waqf funds for HEIs is necessary in order to reduce the burden with regards to their allocated governmental budget where may have challenges on the application of waqf funds for financing HEIs in Bangladesh (Ahmad \& Hassan, 2007).

It is clear to note that a substantial part of the overall population faces a number of obstacles when aiming to attain higher education. Thus, if the allocated budget is minimized, this will have a drastic effect on the number of students enrolling in HEIs. Further, academic talent will remain undiscovered due to financial circumstances, and lack of grants, scholarships, and fee waivers. As a result, this reinforces the distributive justice problem that belonging to a poor family becomes a crucial factor in one's professional success and achievements.

\section{DEVELOPMENT OF WAQF FUND FOR HEIs IN BANGLADESH}

In Bangladesh, Waqf's advancement is influenced by various challenges. Some of them are exceptionally incorporated waqf organizations, deficient labour, absence of authoritative and managerial strength, those are not registered waqf fund, nonattendance of plans in the critical laws, absence of social mindfulness, illegal occupation, and unauthorized waqf properties, operational wastefulness, uprightness and capability of Mutawalli and absence of Shari'ah and advisory board. Such difficulties have essentially influenced the trust among partners and have restricted waqf's commitment to easing neediness from Bangladesh (Sadeq, 2002).

Karim (2010) has cited that waqf is being overseen by the administrative authority in an exceedingly incorporated condition (Karim, 2010). Besides, Stibbard, Russell, and Bromley (2012) take note of that the individual utilization of remuneration cash, which is sourced from the procurement of waqf fund in Bangladesh, has been created by Mutawallis oppose to Bangladeshi authorities. These protests alone can be unsafe for the waqf foundation which is worked based on trust (Stibbard, QCT et al. 2012).

Moreover, Blind (2007) pointed out that Mutawallis has regularly disregarded the original purpose of the waqif in managing waqf funds that have diminished the dimension of waqif's trust. Some of the studies noticed by The World Economic Forum and United Nations Online Network in Public Administration and Finance (UNPAN) confirms that decreasing trust in general sector organisations in apparent in several places of the world. Such studies have noted that there exists a constant decrease of trust within a range of general foundations, in both upgrade and upgrading countries (Hasan \& Siraj, 2016).

As aforementioned, one among the many challenges of waqf administration in Bangladesh is the absence of relevant rules and laws. In their research, Moore and Ryan (2006) 
emphasize that They proceed to mention that "the Waqf Ordinance, 1962, is the main administrative body which gives general rules to the controlling authority. Guidelines in regard to the recording procedures indicate the administrative regulation regarding waqf. These sections also give some essential regulations about the mechanisms of waqf in Bangladesh. The ordinance has put reporting of announcing of the statement's mandatory to the only managements by the Mutawalli, which has enabled reporting to different partners voluntary. As of now, yearly records are arranged and disclosed to the internal administration. The record shows that there 37 administrative zones having separate zonal local offices in Bangladesh.

The record also shows that the annual subscription rate collection is not enthusiastically favourable, a big part of the cash still seems to stay unused in the Waqf Administrative Office. The record below demonstrates the statistics.

Table 2. Yearly total income and expenditure

\begin{tabular}{|l|l|l|l|l|}
\hline No & Fiscal Year & $\begin{array}{l}\text { Total Income } \\
\text { from annual } \\
\text { subscription) }\end{array}$ & $\begin{array}{l}\text { Total } \\
\text { Expenditure }\end{array}$ & $\begin{array}{l}\text { Total } \\
\text { Surplus }\end{array}$ \\
\hline 1 & $2008-2009$ & 28319045 & 25319045 & 3318045 \\
\hline 2 & $2009-2010$ & 32981809 & 29981809 & 3981809 \\
\hline 3 & $2010-2011$ & 41343409 & 35343409 & 6343409 \\
\hline 4 & $2011-2012$ & 48292215 & 45292215 & 3292215 \\
\hline 5 & $2012-2013$ & 54120888 & 50120888 & 420888 \\
\hline 6 & $2013-2014$ & 52010362 & 50010362 & 2010362 \\
\hline 7 & $2014-2015$ & 58662287 & 56662287 & 2662287 \\
\hline 8 & $2015-2016$ & 100318793 & 80318793 & 2318793 \\
\hline
\end{tabular}

Source: Annual report 2016, Office of the Administrator of Waqf, 1

According to the above record, it demonstrates that an enormous quantity of cash stays unused every year, but there is no noticeable practical strategy for the adequate and effective use of this surplus cash.

Additionally, (Alias, 2012) maintained that waqf intuitions should be regulated by specific methods, and perhaps even method of ethics, in the hope that such a method will help to regulate control over waqf assets, thus allowing them to reduce accountability. With regard to non-profit organisations like waqf projects, a strong governance structure has the potential to improved accounting and management practices, thus increasing performance levels (Torres \& Pina, 2003). However, supporting evidence to demonstrate that such an implementation will strengthen waqf institutions is non-existent in Bangladesh.

There is a current indication of waqf institution's revival in Bangladesh's recent past and current aim which is cash waqf. Cash waqf generated fund and it was initially helping in creating few higher learning institutions, particularly some private universities (Sadeq, 2002).Therefore, waqf of cash should function in order to ensure the continuity of waqf according to established principles by creating basic resources for the waqf fund.

\footnotetext{
${ }^{1}$ Report on Waqf regulation in Bangladesh 2016, Retrieved from https://waqf.portal.gov.bd/sites/default/files/files/waqf.portal.gov.bd/annual_reports/0cf9f56e_f404_46c1_b7af_b26652197e9d/7 $\% 20$ years\%20Succ.doc...pdf
} 
Following the above discussion, the below sections provide some prospects in order to raise and development of waqf funds for financing higher educational institutions. The strengthen on raising and developing waqf fund to finance the higher educational institutions are in accordance with scholars, experts that there are several challenges in its implementation. Thus, improvement and suitable solution in this area need to be explored.

\section{RESEARCH METHOD}

This paper has followed the qualitative method, as this research has discussed problems of financing higher educational institutions by waqf fund in Bangladesh. This research also followed three main methods in collecting data namely, data documentation from institutions, library research and interview from directors, academicians and scholars. In this research, the interview was conducted as a primary source to know the technique on how scholars, academician and heads of institutions are involved and find the sources of financing higher education. The researchers met with the selected interviewer and then conducting the interview in a person.

Table 3. In-depth interview participants by religion, Nationality and gender.

\begin{tabular}{|l|l|l|l|l|}
\hline Abbreviations & Interviewer & $\begin{array}{l}\text { Region \& } \\
\text { Nationality }\end{array}$ & Gender & Date \&year \\
\hline R-1- Scholar-M & Scholar & Dhaka-Bangladesh & Male & $\begin{array}{l}\text { 09 October } \\
2015\end{array}$ \\
\hline $\begin{array}{l}\text { R-2-Academician- } \\
\text { M }\end{array}$ & Academician & $\begin{array}{l}\text { Chittagong- } \\
\text { Bangladesh }\end{array}$ & Male & 26 May 2016 \\
\hline R-3-Director-M & Academician & $\begin{array}{l}\text { Dhaka- } \\
\text { Bangladesh }\end{array}$ & Male & $\begin{array}{l}8^{\text {th }} \text { October } \\
2017\end{array}$ \\
\hline R-4-CEO -M & CEO & Dhaka-Bangladesh & Male & $\begin{array}{l}8^{\text {th }} \text { October } \\
2015\end{array}$ \\
\hline R- 5-Head-M & $\begin{array}{l}\text { Head of } \\
\text { Institution }\end{array}$ & Sylhet- Bangladesh & May 2017. \\
\hline
\end{tabular}

Interviews were audio-recorded and sometimes spoke in Bangoli language were translated into English by a bilingual team member who has stayed at Bangladesh then verified for accuracy by a second bilingual team member. The structure and interview method were used for the comprehensive content for analysis of the data. The analysis of this data absorbed by reading and open-coding transcripts to formula tea coding scheme.

\section{FINDINGS AND DISCUSSION}

There are some significant challenges for Bangladeshi higher educational institutions in order to raise and develop the waqf fund for financing them. These challenges are (1) Social awareness about the importance of the waqf Fund for HEIs, (2) lack of organizational and administrative competence, (3) Financing rights of waqf fund for HEIs. The following section provides a discussion on the developing waqf fund for financing HEIs with the opinion of academicians, directors, head, CEO and scholars. 


\section{Lack of Social Awareness}

The practice of waqf funds in Bangladeshi higher educational institutions is limited to endowing land for mosques and graveyards, and this is due to the lack of social awareness about the importance of waqf funds for financing higher educational institutions in Bangladesh. Another reason for lack of social awareness is due to its non-emergence by the scholars which could assist to initiate several waqf fund awareness programs like the seminar, talk and other activities among society (R- 1- Scholar -M- October 2015).

Therefore, this is the main issue revealed from the interview, that lack of awareness about waqf fund for financing higher educational institutions in Bangladesh is a barrier to harnessing their potential to raise fund and impacting positively on the practicing fund for financing the HEIs. Thus, the scholars of Bangladesh should utilize the significance of waqf funds for funding HEIs in different platforms of society and at the same time, the media should follow up consciousness on the importance of waqf funds for reviving the higher educational institution by raising waqf fund. The support from the authorities, professionals and the society is required to revitalize and enhance waqf funds as a significant Islamic institutional in Bangladesh.

\section{Lack of Organizational and Administrative Strengthen for Financing HEI}

The issue of waqf fund development by strengthened the organizational and administrative competency in order to achieve maximum utilization of waqf funds for financing higher educational institutions. Office of the administrator of waqfs Bangladesh (OAWB) have not been very successful in utilizing waqf fund to finance the higher educational institution in Bangladesh. As aforementioned, compared to the magnitude of the total number of waqf funds in several states of Bangladesh, the number of officials managing the waqf fund sector is minimal. This issue happens because of the absence of proper planning, management and enough staff. Waqf fund development requires good waqf managers who are able to manage and develop fund. This requires training of officers in project management or outsourcing to another entity. As such, for the purpose of appropriate administration and managerial board of such an impressive amount of waqf fund dissipated everywhere throughout the country, the awqaf sector needs a significant number of competent staff for generating more waqf fund and developing the existing waqf fund to finance higher educational institutions which is very much needed to develop (R-3-DirectorM- October 2017).

\section{Lack of Waqf Fund Development Initiatives}

In Bangladesh, the reason for the less number of waqf funds in higher educational institutions is that there is no enough initiative for developing waqf funds by HEIs and which has confessed that the waqf fund development initiative is lesser than the need of financing higher educational institutions in Bangladesh. Concerning the concept of waqf fund, (R-2- Academician-M-26 May 2016) mentioned that authorities should have much awareness of raising numerous projects based on waqf funds. The society also lacks awareness on the importance of contribution to waqf fund for financing higher educational institute. In this case, the government, scholars and researchers should focus on introducing waqf funds for financing higher educational institutions. The society also does not aware about the importance of giving waqf funds for financing a higher educational institute (R- 5-Head-M-May 2017).

Moreover, (R- 1- Scholar -M- October 2015) points out that the role of waqf fund in Bangladesh is lacking several numbers of initiatives especially raising cash waqf from staff, alumni and students for development projects in order to raise waqf fund in the higher 
educational institutions. Therefore, it is imperative to raise and develop the waqf fund by initiating numerous projects in higher educational institutions in Bangladesh.

(R-3-Director-M-October 2017) mentioned that some higher educational institutions, e.g. Hamdard University Bangladesh and IIUC had initiated some projects for the purpose of raising waqf funds in Bangladesh. There are many higher education institutions which still relies on raising waqf fund for financing their HEIs. (R-3-Director-M-October 2017) firmly believes that higher educational institutions in Bangladesh should introduce more projects in order to raise waqf funds.

Based on the field study, there are few reasons for the lack of development initiative of waqf fund which are: (1) Lack of Research, (2) lack of support from the government. The following subsections provide details on these points.

\section{Lack of Research Activity in order to Raise Waqf Fund for Financing HEI}

In Bangladesh, the lack of research which is the first limitation to more practice in raising waqf fund. The initial step to innovate more projects is Conducting research in order to raise the waqf funds. However, academician and Shari'ah scholars need to possess a positive attitude to research on waqf funds. (R-4- CEO -M- October 2015) points out that the benefit of research is evident among the academicians and Shari' $a$ ah scholars in Bangladesh. This is the reason for the higher educational institutions and the government is willing to spend money on research. There is very little research conducted in relation to the waqf funds. HEIs and government are generous to finance different big events, at the same time, they should be willing to finance on research as well (R-4- CEO -M- October 2015).

In this regard, (R-2- Academician -M-May 2016) mentions that.

We should see the overall outcome of the research. Perhaps one or two research projects for a certain project of waqf fund cannot bring any outcome but another may bring about a beneficial outcome. Sufficient funding is very important for research.

It may be viewed that spending fund for the purpose of research does not yield any benefit or income compared to expenditure in other are which might produce wages. This reasoning should be changed (R-2- Academician -M-May 2016) argues that research would be done for the purpose of the needs of the community. It must be done in such a way that waqf fund projects can be made something significant for the society rather than merely imitating current projects. Besides this, due to the lack of research, there is less awareness of the public. In many instances, due to the lack of research, the risk of specific beneficial projects can't be minimized. If comprehensive research is conducted, then many types of risks can be minimized (R- 5-Head-M-May 2017).

The researcher believes that HEIS and government can play an important role to widen research on waqf funds in order to raise and develop the waqf fund for financing HEIs. A guideline that every HEI in Bangladesh should have a waqf center and waqf based research division should be developed. This research division should be responsible to research the existing projects of the HEI to identify the shortcomings in those projects. Moreover, it should introduce more innovative projects in order to raise funds for HEIs. The research division should also assist the Shari'ah advisory board to determine the potential Shari'ah violations in projects and the alternative Shari 'ah mechanism for conventional projects. 


\section{Lack of Support from the Respective Authority}

Bangladesh has a considerable amount of waqf fund as explicit above, that might be applied by the higher educational institutions to generate waqf fund by initiating more projects. In this regard, the rules and regulations should be flexible in using waqf funds for raising projects. However, they are sufficiently flexible in other than any current NGO project. For example, currently the existence of "Waqfs Ordinance of 1962" issued as an ineffectively enlisted part of enactment even with the needs of today (Karim, 2010).

Pertaining to this, the authority should broaden the needs of the increasing waqf fund in the country. Waqf fund is increasing day by day because of the staggering response from the general population. As the public are spontaneously opting to contribute to waqf fund for reviving some Islamic institutions. As people, in general, are unexpectedly selecting to support waqf funds for resuscitating some Islamic institutions. However, government support could be like the Malaysian government where the government directly patronizes and hands out projects to find out the sources of waqf funds for financing themselves. In Bangladesh, some educational institutions are moving forward due to public support even though the authority has not been friendly toward it. It is clear that the government does not sincerely support the higher educational institutions in order to raise waqf fund for financing themselves

The expansion of the role of waqf fund would encourage Muslims to participate in higher educational institutions actively, and thus it will contribute to the institutions to be independent without relying on the government fund. Eventually, this will reduce the government's budget for universities. Therefore, the government of Bangladesh should provide at least its approval for practicing various projects for the purpose of raising the waqf fund that was awarded to finance themselves (R- 5-Head-M-May 2017)

\section{Discussion on Prospects of Waqf Fund for Financing HEIs in Bangladesh}

There is a significant prospect of raising and developing of waqf fund for financing higher educational institutions in Bangladesh. This study suggests that waqf based fundraising sources which can be practiced by the higher educational institutions in Bangladesh. Considering the role of the waqf fund framework, HEIs need to finance various sources and develop project structures that have been proposed separately for Bangladesh. The following sections illustrate the proposed sources of structures for the Bangladeshi HEIs. The structure of Each source is explained with figures, underlying conceptual structure, the challenges and possible solutions in its implications.

A few methods of raising waqf funds have been suggested for higher educational institutions in Bangladesh. These are raising funds from various sources, like developing a cash waqf scheme for HEIs in Bangladesh; using Alumni Staffs and students' contributions and Promoting Fund Raising Programs. The details of these sources with various examples based on other country's development are provided below.

\section{Cash Waqf for Financing HEIs in Bangladesh}

Raising funds by cash waqf is a practice for financing a university's development projects. For instance, if any institutions can plan to raise cash waqf funds by their official staff, lecturers, alumni, and student's contributions, in order to bear the costs of a project, HEI management can plan to implement cash waqf fund into a project. The objective of this establishment is to involve all parties' contributions and not to rely on only one financial resource. The management of HEI 
could be expected to drive these objectives with the involvement of staff, students and alumni of HEI in each field both in public and private sectors.

(R- 1- Scholar -M- October 2015) has stated that in order to establish this kind of program, HEI could adopt these approaches to be used for raising the waqf fund:

- Raising waqf funds from various parties. Likewise, a minimum of 200 taka from official Staffs, lecturers, Management and Alumni

- Raising Waqf Funds from students, a minimum of 5 taka (per month) during the registration period.

- Raising Funds from waqf resources. (Revenue from rental, Leasing and capital gains).

It could be taken an example among HEI in Bangladesh, for instance, International Islamic University Chittagong could be an example. This HEI could be expected that raising waqf fund under cash waqf scheme and it will be possible as this HEI have 401 academic staffs, 600 administrative staffs, 15 thousand Alumni and 14 thousand students in the university (Islam, 2018). The estimated contribution is provided in the table below:

Table 4. Raising fund by Cash waqf in Higher Educational Institution

\begin{tabular}{|l|l|l|l|l|l|l|}
\hline SL.No & Contributor & $\begin{array}{l}\text { Minimum } \\
\text { amount } \\
\text { (Monthly) }\end{array}$ & $\begin{array}{l}\text { Total } \\
\text { contributor }\end{array}$ & $\begin{array}{l}\text { Monthly } \\
\text { total } \\
\text { contributor }\end{array}$ & $\begin{array}{l}\text { Yearly total } \\
\text { contributor }\end{array}$ & $\begin{array}{l}\text { Total } \\
\text { contributors } \\
\text { 5 years }\end{array}$ \\
\hline 1 & $\begin{array}{l}401 \text { academic } \\
\text { staffs }\end{array}$ & TK 200 & $200 * 401$ & 80,200 & 962,400 & Tk 4812,000 \\
\hline 2 & $\begin{array}{l}600 \\
\text { administrative } \\
\text { staffs }\end{array}$ & TK 200 & $200 * 600$ & 120,000 & 1440,000 & Tk 7200,000 \\
\hline 3 & $\begin{array}{l}15 \text { thousand } \\
\text { Alumni }\end{array}$ & TK 200 & $200 * 15000$ & $3,000,000$ & 360,000 & Tk 18,000,000 \\
\hline 4 & $\begin{array}{l}14 \text { thousand } \\
\text { students }\end{array}$ & Tk 5 & $5 * 14000$ & 70,000 & 840,000 & Tk 4200,000 \\
\hline 5 & $\begin{array}{l}\text { Total overall contribution from staffs, management, alumni and students } \\
\text { would be in 5 years }\end{array}$ & $\begin{array}{l}34,212,000 \\
\text { around more } \\
\text { than 34 Million ) }\end{array}$ \\
\hline
\end{tabular}

Source: (Islam, 2018)

The cash waqf scheme in the previous table which is based on the discussion is based on the recent phenomenon, the cash waqf structure is free to be practiced in Bangladesh as it is on par with the standpoint of Shari'ah scholars. As the Shari'ah Scholars accepted the cash waqf concept, then, cash waqf funds by raising money should be practiced by the suggested universities from their staff, alumni and students. Scholars suggested that in order to practice this, a project would be developed by these universities or if this fund is insufficient, it could be integrated with other waqf fund concepts, e.g. waqf share fund and develop any of the university projects. For example, the project can be planning to develop a complex which includes mini markets for the usage of students and staff (R- 1- Scholar -M- October 2015). 
Authors also suggested that this cash waqf fund can be used for developing this project which would be raising funds from this complex to developing another project. The following section will explain the details about developing a project complex by integrating cash waqf and waqf share funds.

\section{Waqf Share for Financing a HE Institutional Project}

Most of the scholars are agreed on Waqf-share which is one of the methods to generate funds. (R-1- Scholar -M- October 2015) has suggested that the generation of the fund can be practiced widely as fundraising for fund collection in Bangladesh. The way of issued waqf share which can be started by the trustee, with no fixed amounts. Consequently, anyone can share the minimum fund that he can afford. The contributor then can buy these waqf-shares, they can be created waqf fund which is going to be converted into projects, especially few universities as planning for a long time to develop a complex project and hence this waqf share instrument is suitable to raise fund for this project. Hence HEI and the beneficiaries will gain benefit from their educational institute.

On the other hand, (R-2-Academician- May 2016) opined that raising waqf-shares is not only for fund collection but also to promote others in order to participate and develop their higher educational institutions, in spite of their wealth, with any amount of fund they able to pay. The Bangladeshi people have always welcomed and participated in activities that are a spiritual attribute which motivates to contribute as voluntarily work in order to achieve rewards basis on double and multiplied until the Day of Judgment which mentioned in prophetic narration in the below hadith:

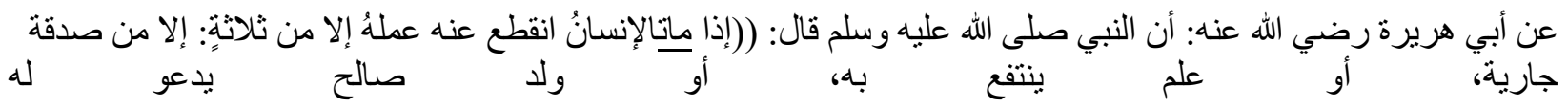

Translation: "Abu Hurairah (Allah be pleased with him) reported Allah's Messenger $(P B U H)$ as saying: When a man dies his acts come to an end, except three things, recurring charity, or knowledge (by which people benefit), or pious offspring, who pray for him "'2.

\section{The Structure Waqf-Shares for Complex Project}

As discussed above a project that HEI can be planned to be developed by utilizing waqf funds which are raised from cash waqf but the cash waqf fund is not sufficient for developing the complex project. In this situation, the HEI waqf trustee can use the waqf share instrument in order to raise the fund and develop the project.

As mentioned above, waqf shares can be defined as transferring an amount of money by a contributor to waqf-shares in order to support the general good and welfare of the society (Mohsin, 2012).

- As the trustee to manage that fund, HEI would be issued the waqf share.

- The different levels of interested founders of waqf share buy the waqf share for the waqf to be efficient, interested developers at various levels purchase shares from TK 10, TK 20 and TK 50 for each share, and then send it to university trustee to handle as trustee.

\footnotetext{
${ }^{2}$ Narrated by Muslim, the Hadith explaining in book of wasiyyah and chapter which is related to earning reward after death.
} 
- The developers of this waqf share project are not allowed to achieve any amount of profits as this is a waqf fund. In return, HEI trustee will send a certificate for a developer of this project as the proof of contribution for this project;

- The HEI trustee will direct the accumulated capital of waqf share fund from selling all the waqf shares for the specified project which is building a complex such as building including a training center, Islamic school and mini markets, etc.

- These capitals of waqf-shares will then be used by the HEI trustee as an organization that was introduced as a trustee to maintain and utilised their fund and gathered funds to that complex project. This can be further clarified in the figure below

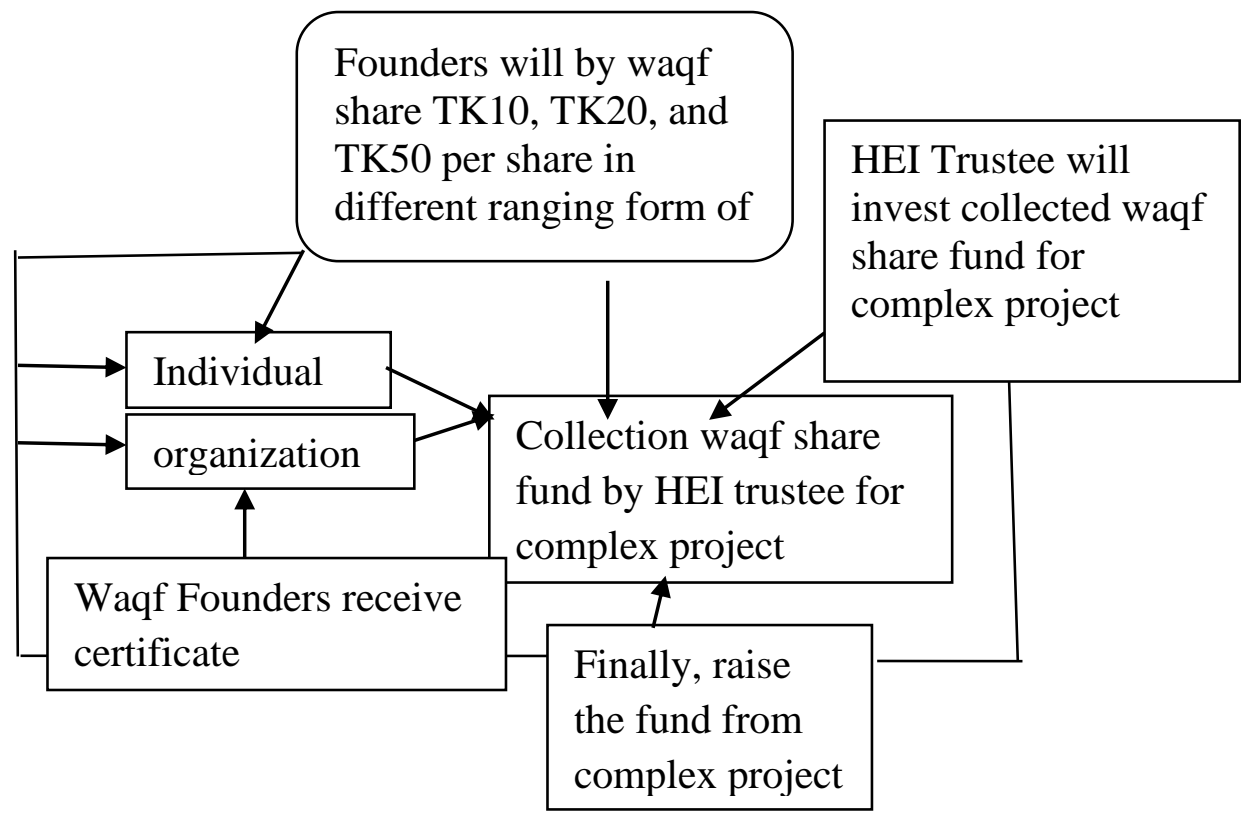

Fiqure 1. Waqf share project in HEI

Source: Annual Reports of State Islamic Councils, 2016.

The figure above has explored the expected waqf share fund for complex projects in an HEI in Bangladesh. The researcher has explained this structure based on the Malaysian waqf share structure (Mahamood \& Ab Rahman, 2015). In Malaysia, as implemented many projects by implementing waqf share fund like, waqf share scheme has been developed by the YADIM and YPEIM (Mohsin, 2003). However, Waqf share is not a very familiar instrument in Bangladesh and the Shariah scholar also did not discuss the waqf share. On the other hand, some Shari'ah Scholars has introduced this instrument in other forms of charity, likewise, given fund for developing an academic building and issued a certificate with the name of the donor. In certain case, authority replaced donor with name plate in donated building (R- 1- Scholar -MOctober 2016).

In that case, there will develop a project by using waqf share instruments from any HEIs, it cannot be denied that waqf share will be a very useful instrument in order to raising and development of waqf funds for any higher educational institutions in Bangladesh. With this waqf share instrument, higher educational institutions would be fulfilling their needs and raise funds for developing a project. Therefore, the authority should implement this kind of instrument and 
shariah scholars of Bangladesh should consider implementing this waqf share instrument for raising and development of waqf funds.

It is obvious that the waqf fund plays an essential role in financing higher educational institutions by promoting fundraising programs and the development of waqf projects. Theoretically, the vast resources of waqfs can become a powerful instrument not only for the preservation of religious, charitable and philanthropic institutions but also for developing the higher educational institutions. It is of utmost importance that waqf funds should be adequately maintained. So, the need for a pragmatic and empirical approach in the area of waqf fund is obvious. Besides this, the higher education institutions need to take the initiative to develop waqf fund centers in every HEI. In this context, government and HEIs can initiate proper steps to raise and develop waqf funds.

\section{CONCLUSION}

The article highlighted the issues of waqf fund for financing higher educational institutions (HEIs) in Bangladesh. This paper highlighted also some problems in implementing waqf fund for financing HEIs in Bangladesh and offer some possible suggestions solution to make easy and affordable by the implementation of a waqf fund based HEIs. The findings have shown that the role of waqf funds is important in providing financial help to the society of Bangladesh and improving their institutional system. Considering the needs and appropriateness of the higher educational institutions, a number of problems and possible solutions have been discussed for the country. At the same time, a number of prospects have been proposed for the country. Raising funds by collecting Hibah/donation, raising funds by different activities and promoting funds from alumni have been proposed for higher education in Bangladesh. In addition, cash waqf, waqf share and promoting fund by different activities have been proposed for Bangladesh. This article discussed the experience of the waqf fund implementation in some Malaysian higher educational institutions. It is also containing examples from the experience of several earlier higher educational institutions. There are huge potentials for the development of waqf funds for financing higher educational institutions in Bangladesh.

\section{ACKNOWLEDGMENT}

This article is the research output under Grant LRGS entitled "Models of Waqf Financing, Investment and Development of Higher Educational Institutions: A Study in Malaysia And Some Selected Countries (Lr001c-2013b)". The University of Malaya also appointed $1^{\text {st }}$ author of this article under the IGRA scheme during this research. We, therefore, extend our heartfelt appreciation to the Ministry of Higher Education and the University of Malaya for allocating funds for this research project.

\section{REFERENCES}

Ahmad, A. U. F., \& Hassan, M. K. (2007). Regulation and performance of Islamic banking in Bangladesh. Thunderbird International Business Review, 49(2), 251-277.

Alias, T. A. (2012). Venture Capital strategies in waqf fund investment and spending, ISRA International Journal of Islamic Finance, 4(1), 1-54.

Annual Reports of State Islamic Councils in Malaysia (2006). Retrieved from http://www.mais.gov.my/majlis/index.php?option=com_booklibrary\&task=show Category\&catid=48\&Itemid=75. Accessed in October 2007 and re-visited in May 2011. 
Ashraf, M. A., Osman, A. Z. R., \& Ratan, S. R. A. (2016). Determinants of quality education in private universities from student perspectives. Quality Assurance in Education, 24(1), 123-138.

Argun, S. (2013). Elite configurations and clusters of power: the Ulema, Waqf and Ottoman State 1789-1839 (Doctoral dissertation, McGill University).

Ashraf, A. L. I., Hassan, M. K., \& Hunt-Ahmed, K. (2013). An integrated Islamic poverty alleviation model. Contemporary Islamic Finance, 223-243.

Azhari, A. S. (2016). ওয়াকফ অধ্যাদেশ ১৯৬২ ও ওয়াকফ আইন ২০১৩: একটি পর্যালোচনা| Waqf Ordinance 1962 and Waqf Law 2013: A review. ইসলামী আইন ও বিচার Islami Ain O Bichar, 12(47), 85-112.

Blind, P. K. (2007). Building Trust in Government in the Twenty-First Century: Review of Literature and Emerging Issues. In 7th Global Forum on Reinventing Government Building Trust in Government (pp. 1-31). Vienna.

Burrow, G. N. (2008). A History of Yale's School of Medicine: Passing Torches to Others. Yale University Press.

Duruigbo, E. (2004). Managing oil revenues for socio-economic development in Nigeria: The case for community-based trust funds. NCJ Int'l L. \& Com. Reg., 30, 121.

Haron, S. (1998). A comparative study of Islamic banking practices. Journal of King Abdulaziz University: Islamic Economics, 10.

Hasan, R., \& Siraj, S. A. (2016). Complexities of waqf development in Bangladesh. Journal of Emerging Economies and Islamic Research, 4(3), 17-26.

Islam, M. N. (2018). The Status of Automation System at The International Islamic University Chittagong (IIUC) Library, Bangladesh: A Study. International Scientific and Vocational Studies Journal, 2(2), 125-135.

Karim, M. F. (2010). Problems and prospects of Awqaf in Bangladesh: A legal perspective. Ahmad Ibrahim Kulliyyah of Laws (AIKOL), International Islamic University Malaysia (IIUM), Jalan Gombak, Kuala Lumpur, Malaysia.

Mohsin, M. I. A. (2012). Waqf-shares: new product to finance old waqf properties. Banks \& bank systems, (7, Iss. 2), 72-78.

Mohsin, M. I. A. (2003). Integration of Waqfs in the Process of Socio-economic Development: Case Study: Sudan (Doctoral dissertation, International Institute of Islamic Thought and Civilization (ISTAC), International Islamic University Malaysia).

Mahmood, S. M. (2006). Waqf in Malaysia: Legal and administrative perspective. Kuala Lumpur: Penerbit Universiti Malaya.

Mahamood, S. M., \& Ab Rahman, A. (2015). Financing universities through waqf, pious endowment: is it possible?. Humanomics.

Malaysia, K. P. (2012). Malaysia Education Blueprint 2013-2025. Kementerian Pelajaran Malaysia.

Moore, M., \& Ryan, W. (2006). A Framework for Analyzing Nonprofit Governance and Accountability Policies and Strategies. Hauser Centre for Non-profit Organisations.

Mujani, W. K., Taib, M. S. M., \& Rifin, M. K. I. (2016, August). Waqf higher education in Malaysia. In 2016 International Conference on Education, E-learning and Management Technology. Atlantis Press.

Rahman, M., Khan, T. I., \& Sabbih, M. A. (2016). Budget for Education in Bangladesh An Analysis of Trends, Gaps and Priorities. Center for Policy Dialogue. 
Sadeq, A. M. (2002). Waqf, perpetual charity and poverty alleviation. International Journal of Social Economics, 29(1/2), 135-151.

Torres, L., \& Pina, V. (2003). Accounting for Accountability and Management in NPOs. A Comparative Study of Four Countries: Canada, the United Kingdom, the USA and Spain. Financial Accountability \& Management, 19(3), 265-285.

Toutkoushian, R. K. (2001). Trends in revenues and expenditures for public and private higher education. The finance of higher education: Theory, research, policy, and practice, 11, 38.

\section{Copyrights}

Copyright for this article is retained by the author(s), with first publication rights granted to the journal. This is an open-access article distributed under the terms and conditions of the Creative Commons Attribution license (http://creativecommons.org/licenses/by/4.0/). 